\title{
DIETER GRASEDIECK
}

\section{Summary}

The advantage of presence learning is the ability to spontaneously discuss issues and problems with students face to face. Individual learning can be improved by changing teaching methods, for example through project work or tele-tutoring. by combining presence learning with phases of e-learning and also intensive telephone counselling. The following question is the focus of the report: What guiding principles for learning should the teachers at schools or universities strive for in the digital age and how can they implement these guidelines in the work assignments? "The belief that education can, in any case, be replaced by a computer program is a myth. Human contact and mentoring make a significant difference in the learning outcomes", says Sebastian Thrun (Professor at Stanford University and vice president of Google). He looks at both educational traditions, which see the trust and the relationship between the teachers and the pupils or students as the basis of learning, as well as at the results of empirical research on learning. "Even for the digital technology and new media the educational primacy applies: Man is and remains the teacher of man" (Lankau, 2014).

Keywords: Learning methods; Procedure of learning; effective learning; Tele-tutoring; E- learning; Massive Open Online Courses (MOOC)

\section{INTRODUCTION}

To improve the quality of teaching and research some colleges, universities, including universities of applied sciences, in Germany, Romania and other European countries continuously broaden their e-learning offer in specific areas of teaching. In the US this trend is particularly strong. The tuition fees rise each year. A at many universities in the United States the students pay more than $\$ 40.000$. This is reason enough for American society to look for financially favourable study paths, such as e-learning. But can the use of computers at universities replace direct assistance for students and even improve their study? At the International GUIDE Conference in Athens (October 3 to 4, 2013) many American professors argued that the traditional university study must be economic and thus needs to be improved (See Lankau 2014). Therefore, online universities are the universities of the future; they would offer the student the freedom to choose from a growing range of Massive Open Online Courses (MOOC). Instead of a hundred students in lecture halls or classrooms, thousands around the world would follow the best and most dedicated professors. The personal discussions with the professors could be replaced by E-mails. The close relationship between faculty and students at universities in the United States becomes more and more a thing of the past. Online-education will change the world, was the promise made in May 2012 by Anant Agarwal, the president of edX, an online training platform founded by Harvard and the Massachusetts Institute of Technology (MIT). At first there was huge interest. In October 2012, 180.000 students enrolled for the free course CS50x. Not a moment later the New York Times cried out - The Year of the MOOC - . But the hype started to even out rapidly, because less than one percent $(0.8 \%)$ of the registered students acquired their certificate of completion (See Brinck 2015). Furthermore, due to the use of MOOCs the budget at American universities was cut and professorships not filled. Many original proponents refused further cooperation. Especially since the recent experiences show that the dropout rates of online courses are around $97 \%$. Even in the digital university one finds the scorned method of frontal teaching. It is an illusion to believe that a lecture will be better, because it is experienced on the screen instead of in the auditorium (See Brinck 2015). Only the combination of media teaching methods and classroom sessions leads to good learning outcomes. Digital media is useful mostly by those who can afford face to face schooling, and excludes those, who cannot pay for it. "The human contact and mentoring make the decisive difference", says Sebastian Thurn. He includes both educational traditions, which look at the trust and the relationship between the teachers and the pupils or students as the basis of learning, as well as at results of empirical research. "Man is and remains the teacher of man " (Lankau, Ohne Dozenten geht es nicht 2014). The question is how does the professor or teacher have to change or expand the teaching process in the digital age?

\section{THE TEACHING PROCESS IN THE DIGITAL AGE.}

If the computer can already make all the scientific information available at high speed, but only man alone can develop creative thinking and new ideas through discussion. Skills such as creativity, the ability to find links on an intellectual level, drawing conclusions from discussions, social skills and flexibility must be promoted in schools and universities. These abilities that students need can be developed, among others, through more practical experience in business, selforganized learning and interdisciplinary studies.

\subsection{LEARNING SKILLS IN MODERN SOCIETY - PRACTICAL EXPERIENCE IMPROVES OPPORTUNITIES FOR YOUNG PEOPLE}

For example, a number of representative surveys determined that about 60 percent of academics in Germany with up to ten years of professional experience were of the opinion that they were simply thrown into the deep water of professional life in industry or the economy after graduation. Sudden pressure to perform, the inclusion in the company, the conversations with customers, superiors or colleagues increased the difficulties of career entry. The universities in Germany scarcely prepare for professional life, according to the message of the survey (See Guido Augustin , 2011).

These findings, mentioned by both students and managers, clearly show that the theoretical knowledge acquired at universities needs to be more strongly linked to the necessary practical knowledge in enterprises and new practical skills must be developed. Therefore, the EU Commission urges: 1. Greater involvement of dual vocational elements. 2. Better 
connections between universities and the needs of the labor market. 3 . Better student counselling (EUROPEAN COMMISSION Brussels, 2013).

Students need to think multi-dimensionally and see the bigger picture. Therefore, the learning content of the university and the learning content of the economy must be tightly interconnected. For example, through agreements between the university and the economy, the knowledge from lectures and exercises in computer-aided systems and business accounting at universities could be put in practice in a company active in the economy. In light of these developments, the interest in new forms of learning, such as the self-directed, self-determined or self-organized learning, is unbroken and tends to increase further. These new forms of learning offer the possibility of an explosion of knowledge, the requirement of lifelong learning and the need for highly individualised learning pathways come together (Dietrich 1999: 14).

\subsection{SELF-ORGANIZED LEARNING}

The transitions between professional and scientific knowledge are flexible. There is no clear separation between purely theoretical and practical learning content. For skilled workers, it is important to recognise relationships, to independently learn and to act from the findings. Nevertheless, the professors, teachers or lecturers are also not superfluous. However, their role changes radically. Teachers don't provide only specialist knowledge, but enable, help, indicate possibilities, consult and encourage. Nevertheless, this partial functional change of teachers is not connected with a falling support level needed by the learners, as often emphasised. (see Klein o. J: 4).

Self-organized learning is not only an aim of educational efforts, but also a condition and method of innovative teachinglearning processes (see Sembill/Seifried 2006: 93). Thus the existence of the competences that the learners need to be able to steer the learning process efficiently and independently, should on no account be simply assumed. They must rather be systematically developed, which means the learners' competences to plan, design, implement and evaluate their independent learning process need firstly be taught (See http://lehrerfortbildung-bw.de/unterricht/sol/ 04_organisation / 2009). Self-organized learning, operational practice and the theoretical knowledge of the universities can be connected by means of Bachelor or Master theses about practical problems of the economy or industry. Through the close collaboration with the economy the students get to know the operational practice and a manager can convince himself of the new ideas, the engagement and the motivation of the students and take this into consideration in future personnel planning. This procedure is offered to the students at many German universities and in the economy. Thus, students can apply for bachelor or master's theses on the Internet. For example, about 400 students are writing their theses at the companies Continental and Porsche (MHP).

\subsection{ADDITIONAL OFFERS FOR INTERDISCIPLINARY STUDIES}

challenges in the various operating departments. Along a supply chain not only commercial skills are required, but also specialists and The economy in a digitised Europe needs broad knowledge in economics and engineering because of the complex general knowledge beyond the department's borders. Economics students should acquire interdisciplinary expertise during the Bachelor's or Master's program. A closer cooperation and coordination of the study programs of the various faculties at universities will become more and more indispensable in the future. It would be desirable if students of economics could also visit study programs in information technology or humanities and the already existing degree programs would find higher acceptance. How can the guidelines of the teaching process - the connection between theory and practice, self-organized learning and interdisciplinary studies - be implemented in schools or universities?

\section{APPLICATIONS FOR TELE-TUTORNG AT THE UNIVERSITY, VOCATIONAL EDUCATION AND TRAINING.}

Nowadays, small learning groups characterise education at the most prestigious universities in the world in the United Kingdom and the United States. In these cases the workload of students is usually higher than in European universities, but here the teachers evaluate each performance of the student, so that students receive permanent feedback on strengths and weaknesses. Thus, the students are guided at an early stage and continuously towards the areas of their study program, to which they should increasingly turn their attention. This way, even personal questions and problems that may affect the learning progress at the University are addressed (see. Grasedieck 2010 p.21f.) (EUROPEAN COMMISSION Brussels, 2013).

Central for the close relationship between faculty and students is the tutoring system at the Anglo-Saxon universities: the mentoring of students is carried out especially through ongoing dialogue with the tutor. These positive experiences of the universities should be achieved with the help of the tele -tutoring seminar method.

Examples of tele-tutoring courses for vocational schools and universities are presented in the following chapters.

\section{1. APPLICATIONS FOR TELE-TUTORING IN VOCATIONAL SCHOOLS}

In the technical school in Germany and in the vocational school in Romania,, the connection between different forms of elearning and face to face teaching can be seen as an interesting improvement of the teaching process.

Tele-tutoring in the technical schools provides, for example, two ways of application: Firstly, through the implementation and design of self-learning areas. Secondly, through the improved coordination and supervision of project work. Selflearning areas should be offered across disciplines for the learner to be able to accomplish simple tasks for which less attention from the teacher is required. So, the time that is needed in the classroom to ensure sustainable and individual support of the student can ultimately be increased because some tasks can be processed in the context of tele-tutoring packages. 
Project work in part-time technical schools is often designed with the help of a company (link between theory and practice, promotion of creativity, flexibility and social skills). Even today, a teacher, with whom the student is assessing the preliminary and final results, is supervising the learners. Because of the lack of time to care for each individual student at the desirable extent, the use of tele-tutoring methods could bring advantages: the student can e-mail his partial results to the teacher every two weeks, which allows the teacher then to think of and prepare suggestions. If then the teacher and the student meet at a fixed date for the regular computer and telephone meeting, the discussion time can be used more meaningfully and purposefully. Both sides can start from the same level of preparation and thus have more time to solve individual problems of each student, for which the teacher could prepare in detail in advance.

\section{2. APPLICATIONS FOR TELE-TUTORING IN UNIVERSITY MASTERS COURSES}

Another way of meaningful use of tele-tutoring would be to offer university master's degree programs completely in this way. The idea behind this proposal refers to the trend to consider the bachelor's degree according to the Anglo-Saxon model as the first university degree. The governments of the EU Member States have laid the foundations by launching the Bologna Process. In the UK or the US, the bachelor's degree is the normal university degree. A master's exam is usually acquired only in the course of a PhD, so on the way to the doctorate degree.

Additional pressure to take action arises in Europe due to the increasing shortage of skilled workers. It is therefore due to this background, that we can see a broad interest in paving the way for graduates with academic qualifications into the labor market already after the bachelor's degree program, at the same time allowing them to get the qualification of a Master's program while also working. Again, tele-tutoring may be helpful in these cases.

Specifically, the following sequence for one academic year is conceivable: The student is present at the University on two weekends in January. At the end of this phase he receives a creative task, which he concludes in the next two months at home. In the middle of this phase, so after four weeks, the student sends the teachers his preliminary work. The teacher gives suggestions for improvement and other comments and returns the file. He then calls the students to discuss the progress of the work. The investigations of Grasedieck from 1979 and 1990 and the interviews of students at the BabesBolyai University and the University of Bochum in 2007 show, that tasks and study work, which make use of the creativity of the students by promoting less repetition and serving rather as an independent preparation for the teaching process, should be evaluated as the most efficient method in terms of learning success. The support provided by tele-tutoring can emphasise this individually-creative aspect significantly better. After the two-month period for working on the task comes another period of classroom teaching, that takes place over two weekends. This is then followed by another two-month period for creative tasks. This process is repeated seven or eight times a year. The teaching on weekends enables a connection between studies and career (Cf. Grasedieck 2010. S135f.). Still, the maxim is that elearning does not replace the former teaching and learning methods, but rather assures a higher quality. In light of the rapidly changing requirements of the working world in the 21 st century the practical use of tele-tutoring methods as media support for self-directed learning and the theoretical discussion of the educational basics of tele- tutoring as a supplement to classroom seminars is recommended.

By using a variety of seminar methods, supplemented by project work and tele-tutoring, great improvement is possible in the teaching of students in the context of a flexible and sustainable acquisition of knowledge and skills. The proposed activities of tele-tutoring are necessary in order to successfully meet the dramatically changing knowledge demand in an increasingly globalised, cross-border networked world.

As the current developments in the European labor market show the willingness for lifelong learning and flexible acquisition of knowledge and skills are critical to the future employment of workers of all ages.

The personal willingness to contribute to the acquisition of new knowledge and to adapt existing knowledge structures to the changing conditions of the working world can be strongly supported by the tele-tutoring method and optimised in terms of a successful, self- directed learning process. Knowledge in the globalised world does not only increase constantly, it is also subject to a permanent process of professional specialisation.

In order to make lifelong learning parallel to vocational and university life as efficiently as possible, the time and space structures offered by tele-tutoring need to be used. So, the students can also participate in spatially and temporally remote education of high schools and colleges with the help of the tele-tutoring method. Tele-tutoring, together with attendance seminars, is therefore a useful method to complement the training offers and adapt these offers to individualised needs.

\section{CONCLUSION: ONLY PERSON-TO-PERSON LEARNING ENSURES THE COMPETENCES OF THE NEXT GENERATION}

The advantage of personal learning is the ability to communicate spontaneously face to face. A disadvantage is the lack of opportunity to individualise the learning process. This in turn can be made possible by offering tele-tutoring. This method of learning is supplemented by the promising idea of permanent small group support through tutorials. Such tutorial support of learners can be provided both through tele-tutoring and through intensive telephone counselling and it can help improve presence learning as well as online teaching. The goal is not only to mediate knowledge, but also the initiation of an independent learning process. This is only possible in small groups and the tele-tutorial offers a promising opportunity to initiate this process in a time-efficient manner (See Schnohr 2008). "The belief that education can, in any case, be replaced by a computer program is a myth. Human contact and mentoring make a significant difference in the learning outcomes", says Sebastian Thrun. He looks at both educational traditions, which see the trust and the relationship between the teachers and the pupils or students as the basis of learning, as well as at the results of empirical research on learning. "Even for the digital technology and new media the educational primacy applies: Man is and remains the teacher 
of man" (See Lankau, 2014).

If the computer can already make all the information and knowledge of the different sciences available in high speed all over the world, the following question is especially important for schools and universities: „Which competences and abilities are needed by pupils and students in order to be prepared for their future life in a digital world? " Considering facts presented in this report, the answer can only be: The school education and university education must primarily promote the competences and the abilities possessed exclusively by people, such as creativity, the ability to find links on an intellectual level, drawing conclusions from discussions, social skills and flexibility. The abilities can be promoted, for example, through seminars in the field of professional presentation and rhetoric or discussions in professional business ethics at universities, through theses (Bachelor, Master or Doctoral) coordinated between the university and the economy and through internships. Only such measures will prepare young people for the rapid economic development and for the digital age.

\section{BIBLIOGRAPHY}

1. Augustin, Guido. „www.univativ.de ."PR- Agentur GuidoAugustin.com GmbH. 2011. www.guidoaugustin.com. Brinck, Christine. „Massiv gescheitert.“ DIE ZEIT, 29. Oktober 2015: 70. Dietrich, Stephan. „Selbstgesteuertes Lernen - eine neue Lernkultur für die institutionelle Erwachsenbildung?" In Selbstgesteuertes Lernen - auf dem Weg zu einer neuen Lernkultur, von Stephan und andere Dietrich, 14-23. Frankfurt, 1999.

2. Dostal, Werner. Arbeit und Lernen in der Informationsgesellschaft. $11 \quad 1998$. www.wissensgesellschaft.org/themen/bildung/arbeitundlernen.html (Zugriff am 1.2 2008). —. „Arbeit und Lernen in der Informationsgesellschaft." Arbeit und Lernen in der Informationsgesellschaft, 11 1998. 8

3. EUROPÄISCHE KOMMISSION Brüssel, den 19.6.2013 COM(2013) 447 final. Gemeinsam für die Jugend Europas. Ein Appell zur Bekämpfung der Jugendarbeitslosigkeit. Mitteilung der Kommission an das Europäische Parlament und den Europäischen Rat, Europäische Kommission, Brüssel: EU Kommission , 2013.

4. Grasedieck, Dieter. „5 th International Guide Conference - Tele-Tutoring is a chance in a knowledge based society Universita Gugliemo Maroni, Rom." http://www.guideassociation.org/proceedings/Guide_2011/. 11. November 2011. —. „Fit für die Zukunft - Selbstorganisierten Lernens, innovativer Tutoring - Verfahren und lernschwächerer Jugendlicher als erste Schritte zu einer zukunftstauglichere Ausbildung.“ Beruflicher Bildungsweg, Februar $2011: 15$ 17.

5. - - „Fit für die Zukunft - Selbstorganisierten Lernens, innovativer Tutoring-Verfahren und lernschwächerer Jugendlicher als erste Schritte zu einer zukunftstauglichere Ausbildung." Beruflicher Bildungsweg, Februar 2011: 1517. - - Tele - Tutoring fördert das selbstorganisierte Lernen. Klausenburg: Presa Universitara Clujeana / Klausenburger Universitätsverlag, 2010.

6. - - "Tele - Tutoring is a chance in a knowledge based society." Tele - Tutoring is a chance in a knowledge based society. 11. 11 2011. http://www.guideassociation.org/proceedings/Guide_2011/ (Zugriff am 1. August 2015). —. Tele-Tutoring fördert das selbstorganisierte Lernen. Klausenburg: Presa Universitara Clujeana/Klausenburger Universitätsverlag, 2010. http://lehrerfortbildung-bw.de/unterricht/sol/04_organisation/. „http://lehrerfortbildungbw.de/unterricht/sol/04_organisation/.“ 24. März 2009.

7. http:www.bmbf.de/de/3336.php. 4. 6 2008. (Zugriff am 1. 7 2010). http:www.bmbf.de/de/3336.php. 4. 6 2008. Klein, Rosemarie. www.diebonn.de/peojekte/beendet/efil/kongress_klein.htm;. 24. 3 2009. (Zugriff am 2. Juli 2012).

Lankau, Ralf. „Ohne Dozenten geht es nicht." DIE ZEIT, 9. Januar 2014: 61. Lankau, Ralf. „Ohne Dozenten geht es nicht." DIE ZEIT, 9. Januar 2014: 61. Meister, Dorothee M, und Uwe Sander. „Bildung just in time durchs Internet." Zum Bildungswert des Internet, 2000: 115-135. Meister, Dorothee M, und Uwe Sander. „Bildung just in time durchs Internet." In Zum Bildungswert des Internet, von Winfried Marotzki, Dorothee M Meister und Uwe Sander. Opladen, 2000. Reimann, Gabi, und Heinz Mandl. „Unterrichten und Lernumgebungen gestalten.“ In Pädagogische Psychologie, von Andreas u.a. Krapp. Weinheim/Basel, 2006. Schnohr, Christian. „E-learning macht Spass." Tagesspiegel, 25. Mai 2008: Wissen. - „E-learning macht Spass.“ Tagesspiegel, 25. Mai 2008. Schulz. 2015. Schulz, Sandra. „Spiegel Online - Unispiegel.“ www.spiegel.de/spiegel/a-744030.html. 13. 12 2015. (Zugriff am 15.12 2015). - . „Spiegel Online - Unispiegel.“ Spiegel Online - Unispiegel. 13. 12 2015. www.spiegel.de/spiegel/a744030.html (Zugriff am 15. 12 2015). Sembill, Detlef, und Jürgen Seifried. „Selbstorganisiertes Lernen als didaktische Lehr - Lern- Konzeption zur Verknüpfung von selbstgesteuertem und kooperativem Lernen." Zeitschrift für Berufs- und Wirtschaftspädagogik, 2006: 93-108. www.wissengesellschaft.org/themen/bildung/arbeitundlernen.html. „Www.wissengesellschaft.org/themen/bildung/arbeitundlernen.html."

"www.wissengesellschaft.org/themen/bildung/arbeitundlernen.html. 2008. (Zugriff am 1. Februar 2008).

Prof. h.c. Dr. Dieter Grasedieck, Dipl. Ing., Principal at College of Vocational Education (1980 - 1994), Adjunct Professor at the University Wuppertal (1975 - 1982), at Babes Bolyai University in Cluj Napoca (2005 - today) and at University Essen - Duisburg (2005-2014), Member of the German Bundestag (1994 - 2009). Contact: fam.grasedieck@t- online.de

This work is licensed under a Creative Commons Attribution 4.0 International License.

DOI :10.24297/ijrem.v7i5.4331 